\title{
Ambivalent Germany
}

How to deal with migration, Muslims and democracy

2017 | Chapter in an Edited Volume | Accepted Manuscript (Postprint)

available at https://doi.org/10.18452/22577

Final version published as:

Naika Foroutan: "Ambivalent Germany: How to deal with migration, Muslims and democracy". In: Fortress Europe? Challenges and Failures of Migration and Asylum Policies. Edited by Annette Jünemann, Nikolas Scherer and Nicolas Fromm.

Wiesbaden: Springer VS, 2017, pages 123-138. DOI: 10.1007/978-3-658-17011-0_9

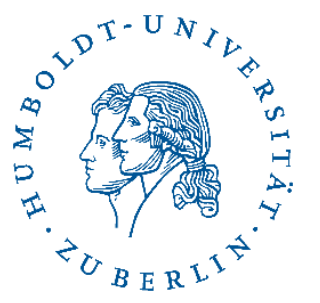

edoc-Server

Open-Access-Publikationsserver

der Humboldt-Universität zu Berlin 


\section{Ambivalent Germany. How to deal with Migration, Muslims, and Democracy?}

\section{Naika Foroutan}

\section{Abstract}

In Germany the recognition to be a country of Immigration only happened in 2001 nearly 50 years after the first immigration contracts with the so called guest workers were signed in $1955^{1}$. This recognition act sets the setting stone for a legal and political empowerment of migrant minorities. These communities have used the legalizing process to put forward their demands for political, social and cultural rights to which society responds in multiple ways. The responses oscillate between new alliances and antagonistic opposition toward immigration. Within this ambivalent society, antiimmigration debates mainly center on Muslims as a target group that is perceived to boycott integration. But anti-muslim attitudes are not only reserved for right wing populists. Due to the omnipresence of the debates they trickle down into the middle of the society and reinforce ambivalences. On one side we can observe a cognitive recognition of privileges such as religious rights as abstract democratic values. On the other hand we can demonstrate empirically that this abstract recognition is withdrawn when it comes to concrete religious rights of Muslim minorities.

This paper showcases the transformation of Germany into a country of immigration, presents figures and statistics on attitudes towards Muslims in Germany and showcases how narrative exclusion of Muslims from the collective German identity can lead to antidemocratic attitudes by denying this minority political participation.

migration - Muslims - society - transformation - stereotypes - ambivalency - minority rights - democracy

\footnotetext{
${ }^{1}$ In September 2000 the Independent Commission of Immigration officially declared that Germany is a country of immigration. This Commission was led by Rita Süssmuth (CDU) and the final report was presented to the Federal Minister of the Interior Otto Schilly (SPD) in July 2001. This report contained recommendation for future immigration policy and is seen as an official, legal and political recognition of being a country of Immigration (Unabhängige Kommission „Zuwanderung“ 2001).
} 


\section{Transformation of Germany into a country of immigration}

According to the latest press releases of the federal bureau of statistics in 2015 net immigration in Germany totalled 1,139,000 people (Statistisches Bundesamt 2016b). That is the largest number of immigrants to enter the country for the last 20 years, since the Asylum Compromise of 1993.The compromise placed tough restrictions on immigration, with the result that the immigration rate significantly decreased in subsequent years. In 2008 and 2009, Germany witnessed a negative migration net outcome, thus making Germany a de facto emigration country (Bundesamt für Migration und Flüchtlinge 2016, 14). First the financial and then the euro crisis both led to increased numbers of immigrants entering Germany from 2010 onwards. At the same time, the German industry has publicly addressed the demographic change occurring in Germany and the country's need for immigration. In 2015, 17,1 million people with a migration background lived in Germany, comprising 21\% of the German population. Of these, the majority (9.3 million) held German citizenship, while 7.8 million were nationals of other countries (Statistisches Bundesamt, 2016c). A quarter of people with a migration background are Muslim; of them, around half possess German citizenship. The majority of people with a migration background living in Germany stem from another European country; in the last five years, this portion of the population has grown significantly as a result of the financial and economic crises. In 2014, almost three quarters of all immigrants $(73.8 \%)$ came to Germany from another European country (ibid., 15). Even in $201558 \%$ of the immigration influx to Germany was from within Europe (Statistisches Bundesamt, 2016b).

These numbers prove that Germany is a country of immigration that has been shaped by significant demographic changes as well as by increasing cultural, ethnic, religious, and national diversity. The meshing of people with and without migration background in the workplace, the family and in everyday life - which fosters the establishment of personal alliances: partnerships, marriages, daughters-in-law and sons-in-law, parents-in-law, 
children and friends - leads to the fact that this migration background is a lived reality for more people than only the migrants themselves, and that the migrant experience therefore is relevant to more people (Foroutan et al. 2014, 38).

Considering the 16 million people with a migration background in Germany, and taking into account the familial alliances formed by the members of this group with people who do not have a migration background themselves, we can say that about $35 \%$ of the total population is in some way affected by this "migration background" category, whereby it becomes increasingly difficult to use migration as the dividing line to distinguish between sections of society, as the migration experience is relevant to an ever growing portion of the population (ibid.). German society's self-perception is increasingly moving beyond the migration aspect and on to negotiating social positioning, rights, and self-concepts in relation to equality of opportunity: Migration and immigration are politically recognized as constitutional elements of society, competing norms and values are being negotiated in a variety of ways, alliances are being developed based on attitudes to diversity, and boundaries against right-wing populist parties are formulated. At the same time, post-migrational societies are witnessing the growth of visibly antagonistic positions, and right-wing populist discourse with strong xenophobic and particularly anti-Muslim rhetoric is gaining an ever stronger foothold in mainstream society (Decker, Kiess and Brähler 2014). These ambivalences are affecting German society during its transformation from a country of immigration to a post-migrational society shaped by immigration and emigration flows, a society that increasingly recognizes its migration reality as fixed and is now ready to find a new self-description that moves beyond the migration aspect.

For decades, from the first Labor Recruitment Treaty in 1955 up until the switch to a red-green government, the German government clung to the stance that Germany is not a country of immigration. However, since the early 2000 s, official political documents have used the term "country of immigration" to describe Germany. The social sciences, seeking to underscore not only the political but also the social change that has resulted from this situation, also use the term "immigration society" (Bade 2013) or "migration society" (Broden and Mecheril 2007). 
The numbers show that there have repeatedly been peaks and declines in the immigration flow to Germany over the last 25 years. If we examine the years 1991 and 1992, we notice a very strong increase in immigration that stems from the fact that in 1992, there was a migration surplus of about 800,000 people ${ }^{2}$ (Bundesamt für Migration und Flüchtlinge 2016, 14). Looking at the years 2008 and 2009, it is noticeable that Germany practically became a country of emigration, as the number of emigrants exceeded the number of immigrants by about 80,000 (ibid.). At the same time, the question of whether or not Germany is a country of immigration was a hotly debated topic during these years, even though it had been officially politically established in the documents of the Süssmuth Committee that Germany was indeed a country of immigration (Unabhängige Kommission „Zuwanderung“ 2001).

While the numbers of immigrants barely changed through the official recognition, the narrative certainly did. The new narrative of Germany as a country of immigration was accompanied by many legal changes. The reformed German citizenship law replaced what was known as ius sanguinis, the blood-based law of nationality that had existed since 1913, which allowed only those who had German ancestors to become German citizens. With the reform of this law in 2001, it became possible to obtain German citizenship based on other criteria that did not include being of German descent. This is a massive change to the narrative of national identity and is in line with modern concepts of citizenship that allow someone to obtain a national identity document without having been born in the country or having ancestors from that country. Furthermore, Germany also passed the Immigration Law as well as laws enabling the recognition of international qualifications and dual citizenship. These changes were ushered in with the help of a new guiding principle - that of "Germany is a country of immigration".

The most recent statistics on immigration in Germany, for the year 2015, show that Germany had an extremely high net total of immigrants of $1,139,000$ that year. After the mentioned significant emigration of 2008 and 2009, Germany experienced increased immigration once again after the financial crisis of 2008 , caused mainly by immigration

\footnotetext{
${ }^{2}$ These large numbers are linked to the violent break up of former Yugoslavia as well as the transformation processes in Eastern Europe which led to intensified migration movements in the 1990 (Bundesamt für Migration und Flüchtlinge, 2005).
} 
from other EU countries. In 2014, 60\% of newly arrived immigrants in Germany stemmed from other EU member states (Bundesamt für Migration und Flüchtlinge 2016, 15). Still in 2015 the majority of the immigrants where coming from the European Union (45\%). If the 13\% immigrants from other European countries further the EU are counted in, even in the big refugee year nearly $60 \%$ of the Immigrants came from Europe (Statistisches Bundesamt, 2016b).

What was the real impact of the increased immigration of 2014, which, compared to other years, was a significant hike in immigrant numbers, in terms of how it was managed by the Länder and how much it increased the population? The Länder such as Saarland, Sachsen-Anhalt and Thuringia experienced a decrease in their populations despite this rise in immigration to Germany; that among all the Länder, Berlin experienced the relatively greatest population increase, though still rather moderate at an increase of 1.4\%; and that the next Länder with the highest rates of immigration, namely Hamburg, Hessen and Baden-Württemberg, experienced immigration rates of just under one percent. In light of the perceptions and the narrative of foreignization in Germany, it is important to put the population increase into perspective by pointing to this value of one percent.

The Federal Statistical Office in Germany published its initial estimates for 2015 at the beginning of the year. Specifically, it published numbers based on what is known as the EASY Registration System, used to carry out initial registrations and pass the numbers on to the Federal Office for Migration and Refugees. These numbers pointed to an initial registration rate of almost 2 million, whereby it is to be expected that this number probably includes double and triple registrations of some of the same people. As a result, the estimates provided by the Federal Statistical Office state that, taking into consideration the number of people who left the country last year, the net immigration in Germany in 2015 numbered about 1.1 million (Statistisches Bundesamt 2016a).

The net migration for 2015 exceeds the standing record total from the year 1992, when about 800,000 immigrants entered Germany. However, it is not an unusually high net migration, seeing as the numbers for 1992 were similar. In 1992, Germany was experiencing a much more difficult economic and structural situation than it is today, shaped by a phase of rising unemployment, the structural and emotional challenges of 
reunification, and a time of intense social unrest throughout the country, especially later on in Rostock-Lichtenhagen, Solingen, Mölln ${ }^{3}$ as a result of increasing racism and xenophobia.

I will conclude the empirical part of this article by asking how Germany has changed and is now represented in its diverse demographic structures. We know that we all have difficulty with the reciprocal practice of categorization. Who is German, who is still a migrant? A foreigner is someone who does not have a German passport - that is a relatively easily definable category. Yet we know that in our daily discourse conventions, "foreigner" can easily be used to describe someone who simply looks different, even if that person has had German passport for a long time or even always had one and never had held any other citizenship. For example, when we talk about pupils in Germany, we have what is known as the Option Regulation, we have dual citizenship. Pupils who start primary school in Germany hold German passports. There is a minimal last percentage category of pupils at Germany primary schools who do not hold German citizenship, i.e. the children of diplomats or stateless Palestinian children. Thus in essence, there are no longer any foreign children at German schools, so to speak. All of them have German passports. And yet it is still part of our daily speech, in our stories, even if it is well-intended, such as when a teacher says, "my German and my foreign children". The realization that Germanness has very diverse elements has not yet become part of mainstream perception.

\section{Attitudes towards Muslims in Germany}

Since September $11^{\text {th }}$ and the subsequent proclamation of the "War on Terrorism", the image of Muslims as terrorists, archaic warriors or anachronistic religious believers has subsequently trickled out of international relations debates and entered the German national Diskurs-Raum (public debate).

\footnotetext{
${ }^{3}$ In the 1990s racist-motivated acts of violence against asylum seekers and people with a migration background in general, increased strongly in Germany. Rostock-Lichtenhagen, Solingen and Mölln stand for fire strikes committed by neo-Nazis which caused many injured people and even deaths (Bundeszentrale für politische Bildung 2013).
} 
This was especially evident throughout the debate that was carried out in 2010/2011 by the Bundesbank's executive board member and former Berlin state finance minister Thilo Sarrazin. His controversial book Deutschland schafft sich ab ("Germany Does Away with Itself") concludes that Muslims are less intelligent because of their cultural ties, that they prefer to live off the state rather than work, and that they have too many children - while well-educated native Germans are having too few. Yet this book has sold more than one million copies, becoming the bestselling book in 2010 .

Common attributes and associations that are being linked with Muslims in Germany are "fanatic", "backwards", "intolerant", or "undemocratic", as a study by the German Institute for Human Rights found (Bielefeldt 2007, 4-5). The study also describes that $21.4 \%$ of Germans think that "Muslim immigration to Germany should be stopped." When asked whether "Muslim culture fits into our Western world ", three out of four respondents answered negatively (ibid). Islam and being Muslim are being perceived as something in stark contrast to being German. In the public eye, a five-year period of massive accusation after 9/11 had turned "the Muslims" into a group with low internal group differentiation and largely a security issue. Moreover, it led to remarkable alienation and estrangement between the constructed Muslim community and the majority non-Muslim society.

A recent study conducted by the SPD-linked Friedrich Ebert Foundation entitled "Intolerance, Prejudice and Discrimination: A European Report" analyzed antidemocratic attitudes in eight European countries. From a comparative perspective it found that "Europeans are largely united in their rejection of Muslims and Islam. The significantly most widespread anti-Muslim attitudes are found in Germany, Hungary, Italy and Poland, closely followed by France, Great Britain and the Netherlands" (Zick, Küpper and Hövermann 2012, 63). Almost half of all Germans said that there are too many Muslims living in the country - even though they make up only 5\% of the population -, that they are too demanding, and that their religion is intolerant (ibid., 61).

A long-term study conducted by the University of Münster investigating the "Perception and Acceptance of Religious Diversity" in a comparative analysis found that Germany has a worse relationship to non-Christian religions when compared to other European countries like Denmark, France, the Netherlands or Portugal. When asked: "How is 
your personal attitude towards the members of the following religious groups?", $62.2 \%$ of surveyed Germans living in the former East German Länder and 57.7\% living in the former West German states answered "negative" or "extremely negative" concerning Islam (Denmark 35.6\%, France 36.7\%, the Netherlands 35.9\%, Portugal 33.5\%) (Pollack 2010, 5). Germans also answered significantly more negative than the compared countries when asked about Hinduism, Buddhism or Judaism. When the same study referred to positive attributions, nearly one third of the Dutch (32.6\%) associated Islam with peace and $44.9 \%$ with solidarity, while in Germany positive attributions of peace and solidarity towards Islam were only given by $6.6 \%$ (former East German states) and 8.1\% (former West German states) of the German population (Danish (25.9\%/ 37.6\%), French (13.6\%/ 31.9\%), Portuguese (19.8\%/ 27.4\%) (ibid., 6).

These biased attitudes are sometimes expressed violently or aggressively: There have been several attacks on mosques, people perceived to be Arab or Muslim have been threatened, organizations receive daily hate mails and anti-Muslim internet blogs have received growing attention (Shooman 2014).

Moreover, on a socio-economic level, people with a Muslim migration background are less likely to be hired or even invited to a job interview when their name doesn't sound "German" enough (SVR 2014), they have a harder time finding an apartment for the same reasons, and children with a "migration background" are less likely to receive a recommendation for continuing with higher education from teachers (Jürges and Schneider 2006).

\section{Narrative exclusion}

Having shown that anti-Muslim sentiments are being broadly examined and researched in Germany, I would like to showcase the outgrouping of Muslims from national identity with an empirical analysis conducted by our research team at the Berlin Institute for Integration and Migration Research (BIM). National identity serves as a cohesive trigger to construct an emotional "we". Being placed outside this collective "we" can mean being placed outside rights to participate politically or socially, to represent one's culture publicly, and even outside legitimate law. Being placed outside 
the collective identity seems even to allow denying minorities (in this case Muslims), fundamental constitutional rights, which is a sign of anti-democratic attitudes.

The empirical data presented here stem from a nationwide representative telephone survey (dual-frame RDD), with 8,270 German-speaking participants aged 16 and above, conducted between 24.09.2013 and 15.04.2014. In one survey experiment, respondents were presented with a variety of statements in which Muslims were compared with a collective "we" that respondents were able to define for themselves in a follow-up question. Two of these statements contained two stereotypes that corresponded to the core stereotypes related to violence and educational aspiration as established in the Sarrazin debate ("Muslims are more aggressive than we are", "Muslim parents have the same educational aspirations as we do."). The respondents were asked to state whether they agreed or disagreed with these statements. The follow-up question was, "And whom were you thinking of in terms of that 'we'?", and was asked openly. The experiment thereby fulfilled two purposes: On the one hand, the goal was to measure stereotypical attitudes towards Muslims, and on the other, we wanted to test a hypothesis previously established within the discursive space, namely one that states that Muslims are not included within the stated "we", and therefore are not perceived as part of the German narrative. (Foroutan et al. 2014)

\subsection{Stereotypical narrative of aggression and lack of educational aspirations}

From research on prejudices and stereotypes, we know that a so-called "outgroup" always has significance for the "ingroup" (Tajfel and Turner 1986; Brewer and Brown 1998). The notions about Muslims that exist in Germany tell us something about the self-perception, fears, and projections of the non-Muslim population (Attia 2007). The references of postmigrant systems in regard to the national and cultural self-perception and perception of foreigners undergo changes over time, and the ideas ascribed to those who are perceived as "others" change along with them. Whereas the others were deemed unpunctual, dirty, and lazy - terms used to describe the guest workers in the 1960s (Hunn 2005) - this mainly served to confirm a German identity, perceived via secondary virtues, and defined in terms of being punctual, clean, and hard-working. Today we describe German identity less via secondary virtues but rather in terms of its 
embeddedness in a European context and described as democratic, tolerant, and enlightened, meaning that the other is described as anti-democratic, intolerant, and having yet to undergo the process of enlightenment. These ascriptions are often associated with Islam and consequently with Muslims (Weidner 2011). These exclusionary value discourses are flanked by stereotypical narratives that often reinterpret and establish socialization factors as characteristics and mentalities and code them as fundamental aggressive tendencies or a genetic lack of educational aspiration, and then ascribe these characteristics to the culture, ethnicity, religion or nationality of the group in question.

$26.5 \%$ of survey respondents agreed with the statement "Muslims are more aggressive than we are," while $64.2 \%$ disagreed with it (see Fig. 1). We see here that the majority of respondents positioned themselves in opposition to the stereotyping of Muslims in regard to aggressive potential. Nevertheless over a quarter of respondents assume that there is something unchangeably "Muslim", namely a high degree of aggressive potential.

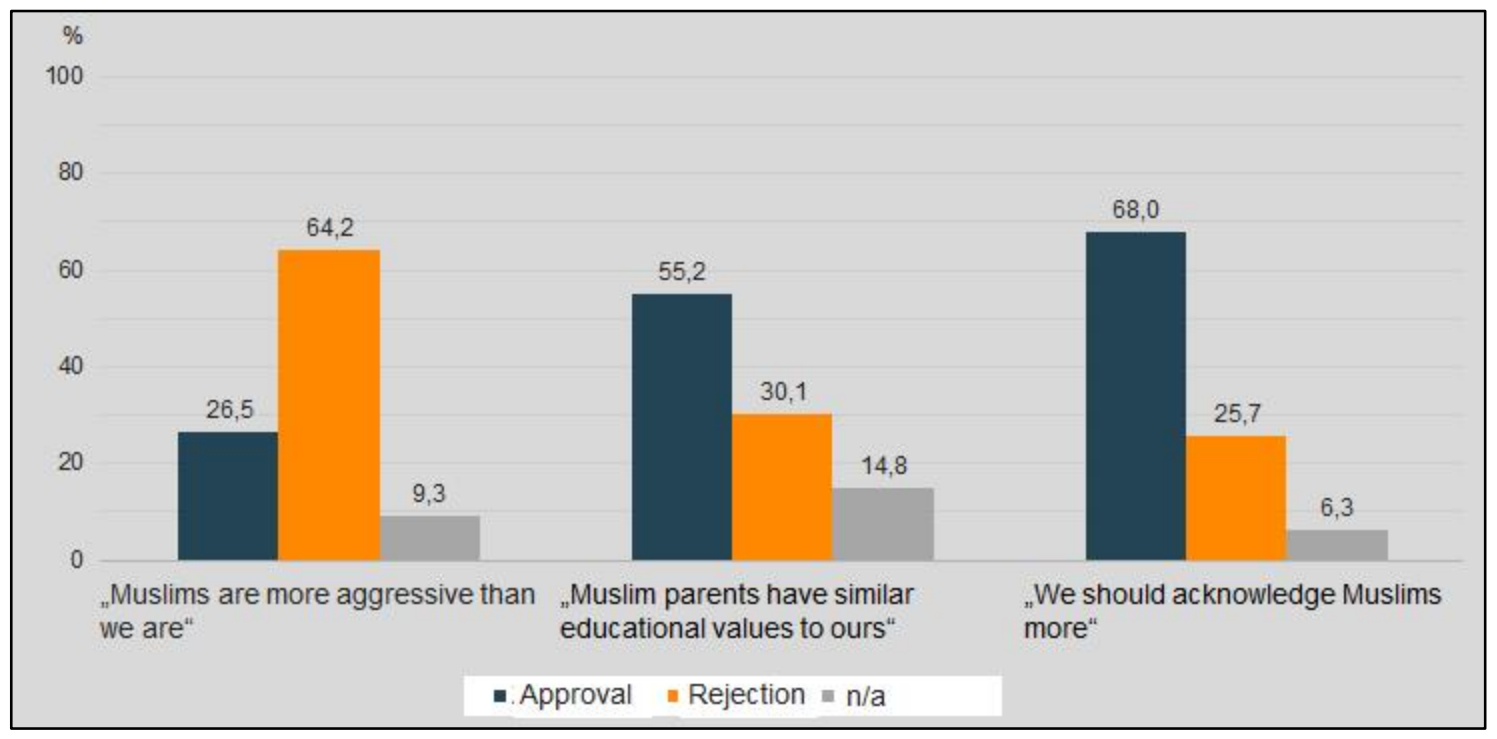

Fig. 1: Exclusion from a national collective (Foroutan et al. 2014, 30)

While most respondents (55.2\%) agreed with the statement "Muslim parents have the same educational aspirations as we do", still $30 \%$ of respondents disagreed, and 15\% answered that they did not know (ibid.). We can conclude from this that little more than half of respondents assume that the topic of education finds equal resonance among 
Muslim families as in their own. The responses to this statement reflect the strong perspective present among Germans that Muslim families are not as interested in education issues as non-Muslims are. However, over the last few years, it has repeatedly been empirically proven that the educational aspirations particularly of Muslim parents in Germany are very high, which coincides with the results of sociological research regarding immigrants' desire for upward mobility.

What stands out in the survey results is that despite the positive response behavior that occurred for both statements, over a quarter of the population took a rather ostracizing or marginalizing stance towards Muslims. While the unchallenged juxtaposition of the ingroup and "the" Muslims is implied within the questions ("Muslims are more aggressive than we are"), most respondents did not question this juxtaposition at all. Only 74 respondents out of the total of 8,215 explicitly criticized the question format. This demonstrates how firmly entrenched the placement of Muslims outside the narrative collective is.

The $u s$-them dichotomy sketched above represents an experimental part of the research question, as respondents were subsequently given the opportunity to further explain their concept of the "we" mentioned in the statements, by being asked by the interviewers: Who did you actually have in mind when using the word "we"?

As this question was designed for open, freely formulated answers, a broad spectrum of responses was collected and subsequently coded and categorized to derive statistical data: $37.6 \%$ of respondents defined the ingroup that they juxtaposed with the Muslims as the ethnic or national category "German" in at least one instance. This includes answers such as "we Germans", "the German population", or "Germany" (ibid., 32). Such answers can be seen as markers of narrative exclusion, as they imply that "German" and "Muslim" are mutually exclusive categories - as if there were no German Muslims and no Muslim Germans. In fact, $45 \%$ of the four million Muslims living in Germany are German citizens (Haug, Müssig and Stichs 2009, 80).

People could have answered differently. For example, they could have said: "By saying 'Muslims are more aggressive than we' are, I meant more aggressive than us, the Christians." Or they could have said: "I meant us, the non-Muslims." Such terms 
would be logical complementary categories to "Muslim", but they were used by only $5.8 \%$ of respondents in at least one instance (Foroutan et al. 2014, 32).

Here again we note the significance of national or ethnic identity that many respondents perceive as being the opposite of a religious category of "being Muslim". This finding supports our observation that Muslims in Germany are excluded from the national narrative. However, it must be pointed out that these findings are based on a survey experiment and that it is not clear what respondents mean when they use national or ethnic categories in their answers. The majority of respondents did not use either of these categories (48.6\%), and provided other factors such as family environment, society, friends, etc., as part of the narrative "we" that they juxtaposed with the term "Muslim". 9.3\% of the respondents would not or could not commit to a definition of the collective "we" and thereby pointed to a perspective that is skeptical of rigid and distinct identities. One of the respondents clearly expressed this contradiction: "That is precisely the problem: There's no such thing as 'the German', 'the Muslim' or 'the Turk', that's what is making this difficult for me." (ibid.)

\subsection{The Ambivalences of being German}

Furthermore in our survey we asked respondents what being German means to them and which criteria are important to the population when it comes to being German. We noted that almost $100 \%$ of respondents answered, "Being able to speak German." A very high number, $80 \%$, said, "Holding German citizenship”. (See Fig. 2) 


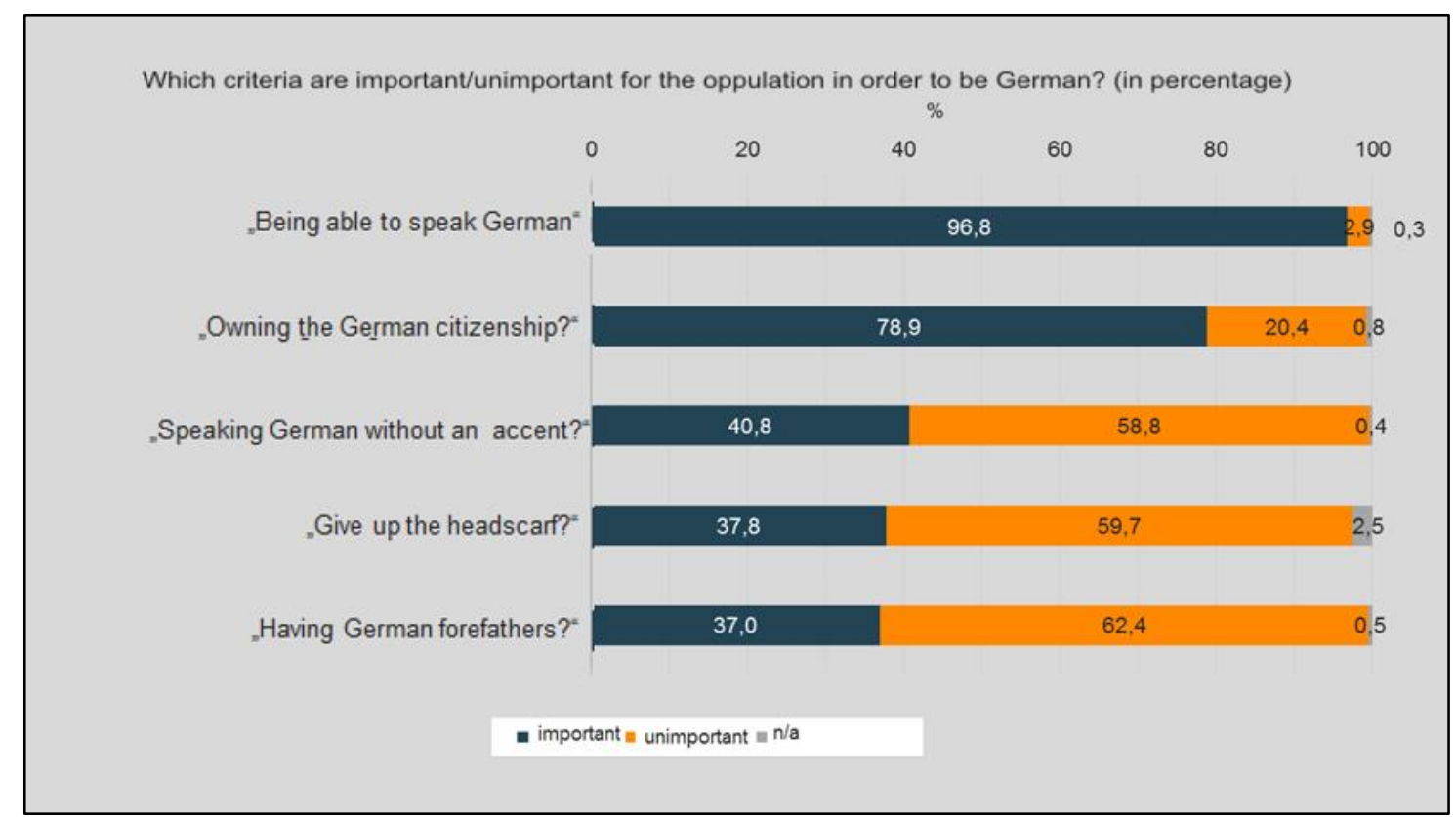

Fig. 2: Conditions of belonging (Foroutan et al. 2014, 25-26)

These are two very unequivocal items that form part of a modern citizenship law. It is recognized that it is possible to become German, and that this requires speaking the language and holding German citizenship. At the same time, respondents limited this possibility, with $40 \%$ noting, "It is not enough to be able to speak German; one must be able to speak it without an accent." In reality, this probably does not refer to dialects, but rather the fact that even small errors in one's spoken German allow listeners to determine that the speaker has not spent his or her entire life in Germany. Making tiny mistakes when it comes to articles allows one to hear that it is a difficult and complicated language that it is sometimes not possible to learn to perfection.

What was of great interest to us when we posed the question about how to deal with minorities was the fact that about $40 \%$ of respondents said that being German required giving up wearing the headscarf (ibid.). This is an ambivalence that I have previously pointed out. On the one hand, there is obviously a high cognitive awareness of the fact that this country has changed, that citizenship has changed, that the country has become more diverse and that ever more people who did not or do not look a certain way and who do not have German-sounding names have become German. Despite this, it is not enough to be able to speak German and to hold German citizenship, if one wears a headscarf, then approximately $40 \%$ of the population believes that you cannot be 
German. Another $37 \%$ are of the opinion that being German really does require having German ancestors (ibid.).

\subsection{Acceptance of equal rights of minorities}

This outgrouping of Muslims from the collective society can also be observed in some controversial debates about the cultural, socio-spatial and symbolic recognition of religious diversity. Discussions about circumcision, mosque construction and the wearing of the headscarf, which we are using here to exemplify the topics of cultural, socio-spatial and symbolic recognition, have repeatedly shaped the political discourse over the last few years and illustrate the restrictions of religious rights with which Muslims are confronted in the German immigration society. How is the cultural, sociospatial, and symbolic recognition of Muslims by the population in Germany regarded?

In our survey, we asked respondents about their attitude to political topics in relation to Muslims, in order to find out how the German population regards the constitutionally legitimized participation rights of Muslims. Three statements dealt with the cultural, socio-spatial and symbolic recognition of Muslims ("The circumcision of boys for religious reasons should be banned"; "A female Muslim teacher should have the right to wear a headscarf in the classroom"; "The construction of publicly visible mosques in Germany should be restricted").

We were able to determine that at an abstract level, recognition was very high, but at the concrete level, there was a lack of willingness to give recognition, participation or participatory rights. The non-Muslim population has an ambivalent attitude to Muslims as visible political actors: On the one hand, a decisive majority (67\%) finds that Muslims in Germany have the right to make demands, and almost an equal number of respondents stated that Muslims deserve more recognition. However, 20\% of the population is of the opinion that Muslims making demands is a sign of shamelessness, and $17 \%$ regard it as a sign of thanklessness (see Fig. 3). 


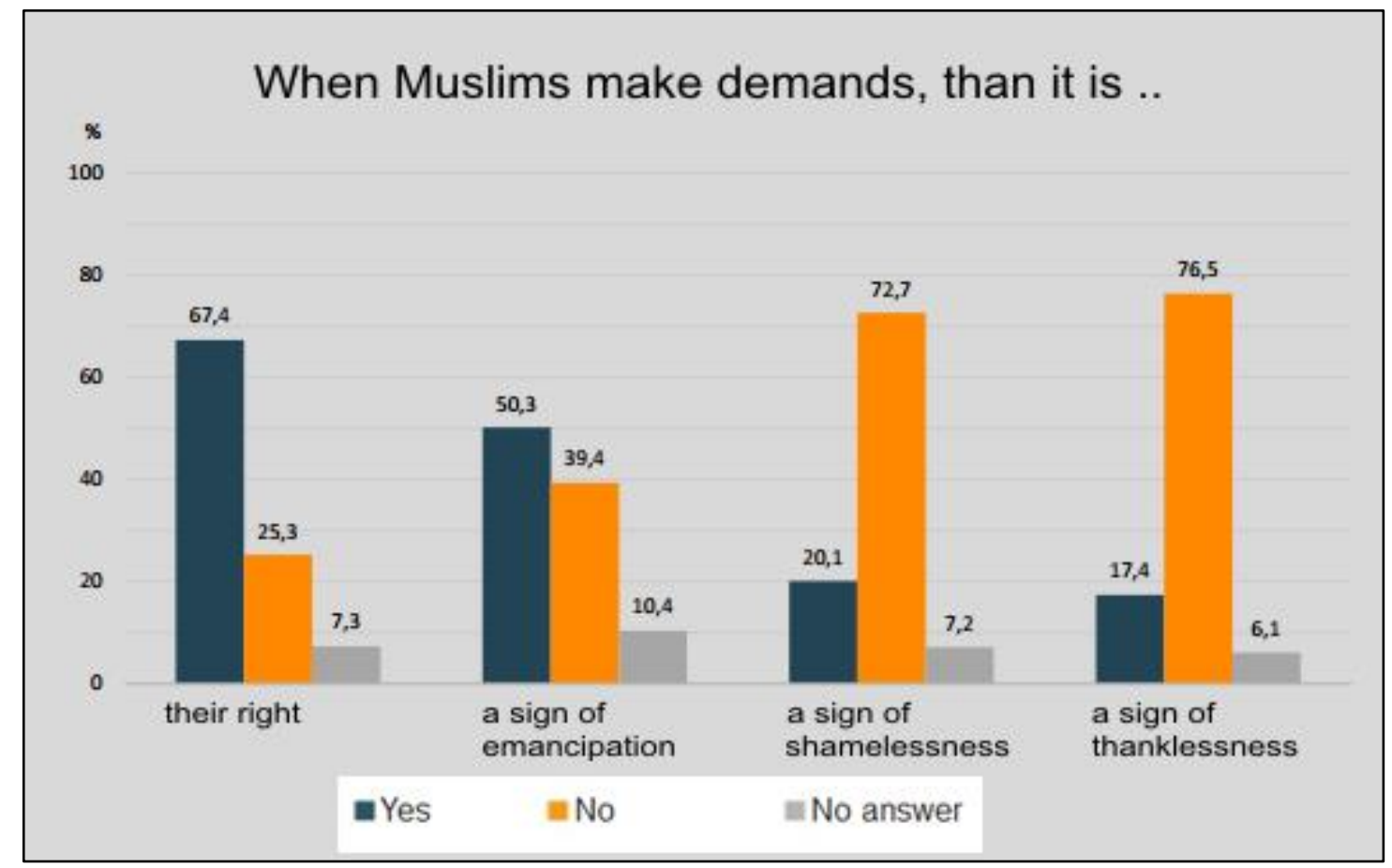

Fig. 3: Cognitive acceptance I (Foroutan et al. 2014, 34)

The ambivalence is particularly expressed in attitudes towards topics of political discourse related to structural, socio-spatial, and symbolic recognition and participations. For example, $69 \%$ of the population is in favor of Islamic religious instruction in schools, but at the same time, $60 \%$ of respondents want to ban the religion-based circumcision of boys. Meanwhile, almost half of all Germans (49\%) believe that female Muslim teachers should not be allowed to wear headscarves in class, and $42 \%$ would like to restrict the construction of mosques. (See Fig. 4) 


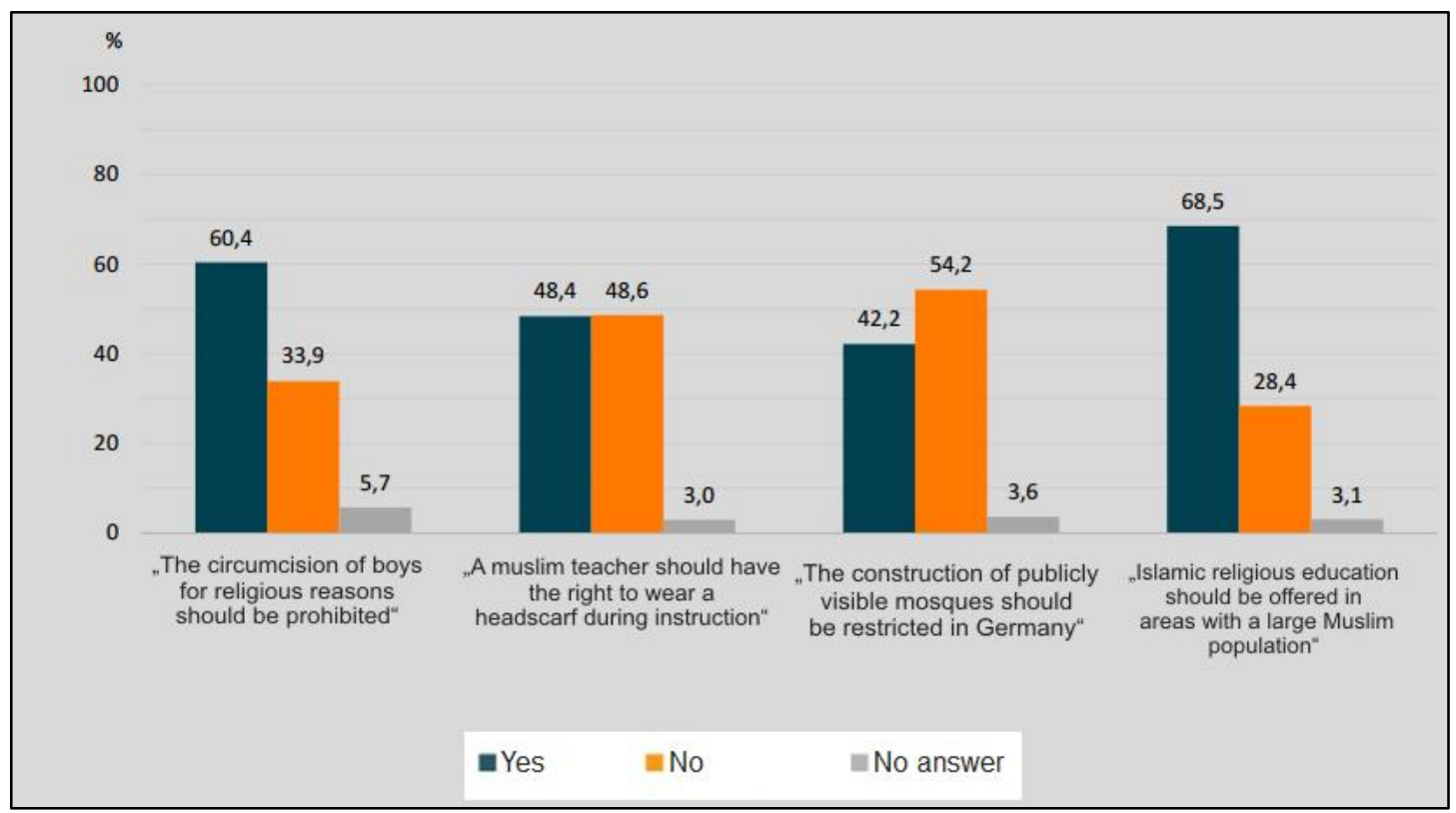

Fig. 4: Cognitive acceptance II (Foroutan et al. 2014, 34-35)

There seems to be an obvious lack of awareness of that which is fixed as a fundamental right as Article 4 in the constitution, namely religious freedom, the freedom to practice one's religion and the right to build places of worship, and the right not to be impeded in the practicing of one's religion. At the same time, we can observe - the debate is once again highly topical, in December 2015 throughout the Christmas season it was very active - that there is a great deal of agreement within the population in regard to passing a law that stipulates immigrants' obligation to ostensibly

German fundamental values. A large portion of the population is of the opinion that such a law should be introduced. But the question is whether we can really achieve progress if we regard integration merely as an obligation on the part of minorities while neglecting to ask what role the majority society should play in the integration process. The debate about the questions of the minority's obligation to integrate revolves around core beliefs related to homosexuality and gender equality. The question that all could ponder together is whether it would be sensible, instead of a one-way obligation to integrate, to think about a collective integration contract that every one of the society signs. Because the question is, in fact, whether there are certain core points that we have established within the constitution and that we must all adhere to. 


\section{Conclusion}

German citizens have a positive image of Germany and they identify themselves strongly with their country but as latest empirical data shows Muslims are not perceived as parts of the national narrative.

Excluding attitudes towards Muslims are accompanied by stereotypes. 27\% of the respondents perceive Muslims to be more aggressive than "their own group" and 30\% think that Muslims' educational aspirations are lower than "their own group". When asked for a definition of this "own- group", nearly $40 \%$ of the respondents use an ethnical or national category like "we Germans", "the German population" or "the German society". Being Muslim and being German are perceived as two opposite categories. In this regard Muslims are defined outside of the "German we".

The citizens of Germany have an ambivalent position towards Muslims as visible political agents. On a more abstract level, German society is willing to accept the participation rights of Muslims, but on more concrete levels, crucial rights are refused: A majority of the population (67\%) accepts the right of Muslims to claim rights in Germany, but simultaneously $60 \%$ of the respondents refuse to accept the ritual of circumcision for boys. Nearly every second respondent (48\%) supports the statement that female teachers should not wear a headscarf, and $42 \%$ would support a legal restriction on the construction of mosques. Only Islamic religious instruction in schools is accepted by most of the citizens (69\%).

The first analysis illustrates that citizens with a strong affiliation with German identity, i.e. people who emphasize the importance of being seen as German, are more likely to deny cultural-religious, social-spatial and symbolic rights (ibid., 36). Accordingly, 68\% of this group are against the ritual of circumcision for boys. $56 \%$ support the statement that female teachers should not wear a headscarf, and 55\% would support a restriction on the construction of mosques. On the other hand, people with a lower level of national attachment are more likely to include Muslims. 54\% of this group are against the ritual of circumcision for boys, $43 \%$ support the statement that female teachers should not wear a headscarf, and 35\% would support a restriction on constructing mosques. 
We can summarize by saying that the willingness to exclude Muslims from the collective German narrative refers not only to discursive, identity, and emotional positions, but to the fundamental question of accepting democratic rights of minorities: practicing one's religion and constructing places of worship are -with specific restrictions - fundamental civil rights. Negative attitudes do not necessarily lead to action, but if we witness 75 attacks on mosques and 1031 attacks on refugees and their shelters during the last year (Meisner, Tretbar and Keilholz 2016), that must be seen not only as clear criminal acts but also as a lack of basic knowledge about democracy . Heterogeneous societies shaped by migration discourses must therefore more thoroughly educate their populations about democratic principles if they want right wing populism to be stopped. 


\section{Literaturverzeichnis}

Attia, Iman. 2007. Orient- und IslamBilder. Interdisziplinäre Beiträge zu Orientalismus und antimuslimischem Rassismus. Münster: Unrast.

Bade, Klaus. 2013. Kritik und Gewalt. Sarrazin-Debatte, 'Islamkritik' und Terror in der Einwanderungsgesellschaft. Schwalbach: Wochenschau Verlag.

Bielefeldt, Heiner. 2007. Das Islambild in Deutschland. Zum öffentlichen Umgang mit der Angst vor dem Islam. Second edition.Berlin: Deutsches Institut für Menschenrechte.

Brewer, Marilyn, and Rupert Brown.1998. Intergroup relations. In The handbook of social psychology, Eds. Daniel Todd Gilbert and Susan T. Fiske, 554-594, Vol. 2, fourth edition.Boston, MA: McGraw Hill.

Broden, Anne, and Paul Mecheril. 2007. Migrationsgesellschaftliche Re-Präsentationen: Eine Einführung. In Re-Präsentationen: Dynamiken der Migrationsgesellschaft, Eds. Anne Broden and Paul Mecheril, 7-28. Düsseldorf: IDA-NRW.

Bundesamt für Migration und Flüchtlinge. 2005. Migration, Asyl und Integration in Zahlen. 14. Auflage. Nürnberg: Bundesamt für Migration und Flüchtlinge.

Bundesamt für Migration und Flüchtlinge. 2016. Migrationsbericht des Bundesamtes für Migration und Flüchtlinge im Auftrag der Bundesregierung. Migrationsbericht 2014. Nürnberg: Bundesamt für Migration und Flüchtlinge.

Bundeszentrale für politische Bildung. 2013. 20 Jahre Brandanschlag in Solingen. http://www.bpb.de/politik/hintergrund-aktuell/161980/brandanschlag-in-solingen-2805-2013. Accessed: 15.07.2016.

Decker, Oliver, Johannes Kiess, and Elmar Brähler. 2014. Die stabilisierte Mitte. Rechtsextreme Einstellungen in Deutschland 2014. Leipzig: Universität Leizpig.

Foroutan, Naika, Coskun Canan, Sina Arnold, Benjamin Schwarze, Steffen Beigang, and Dorina Kalkum. 2014. Deutschland postmigrantisch I: Gesellschaft, Religion, Identität. Erste Ergebnisse. Berlin: Humboldt-Universität zu Berlin. 
Haug, Sonja, Stephanie Müssig, and Anja Stichs. 2009. Muslim Life in Germany: A Study Conducted on Behalf of the German Conference on Islam. Nürnberg: Bundesamt für Migration und Flüchtlinge.

Hunn, Katrin. 2005. „Nächstes Jahr kehren wir zurück...“. Die Geschichte der türkischen „Gastarbeiter“ in der Bundesrepublik. Göttingen: Wallstein Verlag.

Jürges, Hendrik, and Kerstin Schneider. 2006. Age at school entry and teacher's recommendations for secondary school track choice in Germany. http://www.vwl.unifreiburg.de/iwipol/faculty_seminar/age_at_school_entry.pdf. Accessed: 15.07.2016.

Meisner, Matthias, Christian Tretbar, and Christine Keilholz. 2016. Dresden und die "neue Qualität der Gewalt". http://www.tagesspiegel.de/politik/anschlaege-aufmoschee-und-kongresszentrum-dresden-und-die-neue-qualitaet-dergewalt/14609440.html. Accessed: 28.09.2016.

Pollack, Detlef. 2010. Studie „Wahrnehmung und Akzeptanz religiöser Vielfalt“. http://www.uni-muenster.de/imperia/md/content/religion_un

d_politik/aktuelles/2010/12_2010/studie_wahrnehmung_und_akzeptanz_religioeser_vie 1falt.pdf. Accessed: 15.07.2016.

Sachverständigenrat deutscher Stiftungen für Integration und Migration (SVR). 2014. Diskriminierung am Ausbildungsmarkt. Ausmaß, Ursachen und Handlungsperspektiven. Berlin: SVR.

Shooman, Yasemin. 2014. “...weil ihre Kultur so ist” Narrative des antimuslimischen Rassismus. Bielefeld: Transcript.

Statistisches Bundesamt. 2016a. Nettozuwanderung von Ausländerinnen und Ausländern im Jahr 2015 bei 1,1 Millionen. Press release No. 105, 21.03.2016.

Statistisches Bundesamt. 2016b. 2015: Höchststände bei Zuwanderung und Wanderungsüberschuss in Deutschland. Press release No. 246. 14.07.2016.

Statistisches Bundesamt. 2016c. Bevölkerung mit Migrationshintergrund auf Rekordniveau. Press release No. 327,16.09.2016. 
Tajfel, Henri, and John C. Turner. 1986. The Social Identity Theory of Intergroup Behavior. In Psychology of Intergroup Relations, Eds.Stephen Worchel and William G. Austin,7-24,second edition. Chicago: Nelson-Hall.

Unabhängige Kommission "Zuwanderung". 2001. Zuwanderung gestalten. Integration fördern. Bericht der Unabhängigen Kommission „Zuwanderung“. Berlin: Bundesministerium des Innern.

Weidner, Stefan.2011: Aufbruch in die Vernunft. Islamdebatten und die islamische Welt zwischen 9/11 und den arabischen Revolutionen. Bonn. Dietz Verlag.

Zick, Andreas, Beate Küpper, and Andreas Hövermann. 2011. Intolerance, Prejudice and Discrimination. A European Report. Berlin: Friedrich-Ebert-Stiftung.

Prof. Dr. Naika Foroutan is a Professor for Integration Studies and Social Policy at the Humboldt-University in Berlin. She is specialized in Integration- and Migration Studies with a focus on Islam and Hybridity. She is Vice Director of the "Berlin Institute for Integration and Migration Research" (BIM) at the Humboldt-University in Berlin. Foroutan is also board-member of the Council on Migration (Rat für Migration), a federal network of scientific experts on migration and integration issues.

\section{Contact:}

Humboldt-Universität zu Berlin,

Berliner Institut für empirische Integrations- und Migrationsforschung (BIM)

E-Mail: foroutan@hu-berlin.de 